\title{
The System of Teaching English at Agricultural Universities in Bangladesh
}

\author{
Snehangshu Shekhar Chanda ${ }^{1}$, Abdul Rahman ${ }^{2}$ \\ ${ }^{1}$ Department of Basic Science and Language, Sylhet Agricultural University, Sylhet, Bangladesh \\ ${ }^{2}$ Deptartment of Agricultural Economics and Social Sciences, Chattogram Veterinary and Animal Sciences University, Chottogram, \\ Bangladesh
}

Email address:

sschanda2002@yahoo.com (S. S. Chanda), clickshibly@gmail.com (A. Rahman)

\section{To cite this article:}

Snehangshu Shekhar Chanda, Abdul Rahman. The System of Teaching English at Agricultural Universities in Bangladesh. International Journal of Language and Linguistics. Vol. 7, No. 6, 2019, pp. 319-326. doi: 10.11648/j.ij11.20190706.20

Received: October 15, 2019; Accepted: November 9, 2019; Published: November 17, 2019

\begin{abstract}
Language means the way of communication by which better understanding, communication can be possible and the learners should be efficient in at least two languages. As a matter of fact the learners at undergraduate level should learn and be efficient in reading, speaking, listening and writing in at least one foreign language. Since English is the most important language for intercultural communication, it is taught from elementary level to university level in Bangladesh. This comprehensive study shows the system of teaching English at Agricultural Universities of Bangladesh. Result indicates that there are generally five Agricultural Universities in Bangladesh and there are several faculties which offer undergraduate and Post-Graduate degree. English Language is taught as compulsory subject at all faculties at undergraduate level. There are some faculties which offer English as Optional Subject which is very rare. Communicative English / Lab English has been preferred to teach in this regard. At the time of teaching especially in the classroom, $85 \%$ teachers use power point and overhead projector and rest use White Board and Marker in the EFL classroom. English Language Practical course is offered to four faculties of Sylhet Agricultural University, four faculties at Shere Bangla Agricultural University, all faculties of CVASU and Khulna Agricultural University. All teachers use English and mother tongue in the EFL classroom to make the meaning clear to the learners. At CVASU a modern equipped Language Lab was found but the authorities of another Agricultural Universities are trying to establish English language Lab. At Bangladesh Agricultural University, there is also a good well equipped English Language Lab. The learners are also interested to learn both languages (mother tongue and foreign language) in the classroom.
\end{abstract}

Keywords: Language, University, ESL, EFL

\section{Introduction}

English as a second or foreign language is used by speakers with different languages. The system of Language education for learning English may be known as English as a second language (ESL), English as a foreign language (EFL), English as an additional language (EAL), or English for speakers of other languages (ESOL). The aspect in which EFL is taught is called teaching English as a foreign language (TEFL). Methods of learning English are highly variable depending on the learner's level of English proficiency and the manner and setting in which they are taught, which can range from required classes in school to University level and even self-directed study at home. In some programs, educational materials (including spoken lectures and written assignments) are provided in a mixture of English and the student's native language to understand well at elementary and secondary level. In other programs, educational materials specially at university level are always in English, but the vocabulary, grammar, and context clues may be modified to be more easily understood by students with varying levels of comprehension [Wright, 2010] [1]. Adapting comprehension, insight oriented repetitions and recasts are some of the methods used in training. However, without proper cultural immersion (social learning grounds) the associated language habits and reference points (internal mechanisms) of the host country are not completely 
transferred through these programs [Wright, 2010] [1]. This is found to a great extent primarily in pronunciation and vocabulary. The importance of teaching English in English is articulated on the textbook and the teacher's guide. As Farooqui [2] indicates that one of the main features of the curriculum is to use English as the only language of instruction. A significant number of researches [3-8] have considered English language instruction policy in education. "Teachers had a tendency of slipping in to Bangla after starting a sentence in English" [9] Variants of English language also exist in both of these countries. This study was undertaken for the following objectives:

i. To find out the system of education in Bangladesh.

ii. To find out the courses of English Language taught at Agricultural Universities in Bangladesh.

\section{Methodology}

The research was conducted from February'2019 to April' 2019. An interview in qualitative research is a conversation where questions are asked to elicit information. The interviewer is usually a professional who poses questions to the interviewee, in an alternating series of usually brief questions and answers. The researchers are examiners of different Agricultural Universities who have extracted information from faculty members of Sylhet Agricultural University, She-re-Bangla Agricultural University, CVASU, Potuakhali Science and Technology University. These universities have been taken under consideration.

\section{Result and Discussion}

\subsection{Education in Bangladesh}

Education in Bangladesh is overseen by the Bangladesh's Ministry of Education. Ministry of Primary and Mass Education are responsible for implementing policy for primary education and state-funded schools at a local level. In Bangladesh, all citizens must undertake twelve years of compulsory education which consists of eight years at primary school level and six years at high school level. Primary and secondary education is financed by the state and free of charge in public schools.

Bangladesh conforms fully to the UN's Education for All (EFA) objectives and the Millennium Development Goals (MDG) as well as other education-related international declarations. Article 17 of the Bangladesh Constitution provides that all children receive free and compulsory education. The University Grants Commission (UGC) of Bangladesh was established on 16 December 1972. It was created according to the Presidential Order (P. O. No 10 of 1973) of the Government of People's Republic of Bangladesh. In 2010, the Government of Bangladesh (GOB) announced bringing out reforms in University Grants Commission (UGC) and decided to change UGC into Higher Education Commission of Bangladesh (HEC) The UGC is the apex body of all the affiliated public and private universities of Bangladesh. It provides fund for "Government Funded Universities" of Bangladesh. Its mission is to ensure the quality of higher education throughout the country. Private universities must obtain permission from UGC before they operate. UGC was designed to maintain the autonomous nature of the universities. The underlying principle is that the Government should not deal directly with the universities, either individually or collectively; instead, it should deal with the UGC, which, in turn, deals directly with the universities. UGC offers scholarships to outstanding students, funds research, and organizes seminars. [10-11]

\subsection{University Education Policy in Bangladesh}

After Bangladesh's independence in 1971, Bangabandhu Sheikh Mujibur Rahman ordered to form a national commission in 1972 to formulate an effective and progressive education policy for the newborn nation. Led by renowned scholar Dr Kudrat-e-Khuda, the commission published the first education policy of Bangladesh in 1974, which was finely tuned to the country's purely secular constitution. However, after the assassination of Sheikh Mujib the education policy was shelved forever and the country's education system continued to run with centuries old ideals and infrastructure.

Later, with the change of the government, new education commissions and committees have been formed to introduce new education policies. From 1988 to 2010, the country got five fresh education policies, however, very few of those policies managed to bring any significant change and improvement in its education sector. It has been a common allegation against many schools following international curricula that they do not teach their students about the history and cultural heritages of Bangladesh. Considering this point, government decided to introduce a new subject called Bangladesh Studies. In this education policy, it has been made compulsory to teach Bengali, Information and Communication Technology (ICT) and Bangladesh Studies up to secondary level in all the educational institutions regardless of their medium of instruction. Ethics has been introduced to the textbooks of of religious studies and these textbooks have been redesigned accordingly. To reduce unemployment, four-year bachelor degree was fixed in this policy as the acceptable higher educational qualification for most of the professions except for university teaching and researches that need special expertise on a particular discipline. Besides, universities were instructed to include three credits of compulsory English and ICT course in all the departments of the universities. Training facility for the university teachers have also been ensured in this policy. [10-11] 


\subsection{Agricultural Education in Bangladesh}

After the independence of Bangladesh in 1971, the university was renamed as Bangladesh Agricultural University, Mymensingh. In order to cater the need of nation and popularizing agricultural education in Bangladesh, a few more colleges were established across the country to produce qualified agricultural graduates. These colleges/ institutes are Institute of Post graduate Studies in Agriculture (IPSA), Patuakhali Agriculture College, Hazi Danesh Agriculture College, Sylhet Veterinary College and Chittagong Veterinary College.

Realizing the contribution of agricultural graduates in the national development of Bangladesh, the government decided to upgrade the newly established colleges into the status of university with varying number of faculties. In succession of this noble process, Bangobandhu Sheikh Muzibur Rahman Agricultural University (BSMRAU) came into existence in 1998, PatuakhaliI Science and Technology University (PSTU) in 2000, Sher-e-Bangle Agricultural University (SAU) in 2001, Hazi Mohammad Danesh Science and Technology University (HSTU) in 2002, Sylhet Agricultural University (SyAU) in 2006, Chittagong Veterinary and Animal Science University (CVASU) in 2006.

Besides the above universities, Dhaka University, Rajshahi University, Khulna University, Noakhali Science \& Technology University are also offering Bachelor and Masters Degree in different disciplines of Biological and Agricultural sciences. Their course curricula are very much similar to those of Bangladesh Agricultural University at Mymensingh.

\subsection{The Importance of English in Agricultural Education in Bangladesh}

English is one of the most widely used languages all over the world. All continents have an English influence, an aspect that relates directly to the British Colonization of many countries of the $19^{\text {th }}$ century and early $20^{\text {th }}$ century. Since many world activities take place in English, it has become a universal language in many parts of the world. Among the most recognized areas of technical education is Agricultural Education. To better understand and master of agricultural knowledge and skills, students should have good command on English language. Most of the faculty members of Agricultural Universities utilize this language in their lecture.

Non native speakers need to learn the language and develop fluency on it. Attending classes that are conducted in English can be a major challenge to non-native speakers, including doing the assignment and submitting thesis which largely have to be done on the language. Once a student graduates from a university, an even greater challenge waits him. If he does not have a good understanding of English, he faces a rough time searching for a job. Communication skills are one of the most important skills that employable graduate requires, technical education must have the ability to verbalize his linguistic process and combine with deep knowledge of agricultural concepts and applications. A non native student of Agricultural Science at a university will find it easier and more beneficial if he first undertakes English class before continuing his professional courses. (http://www.newsbangladesh.com/english/details/10341) [12].

Table 1. A list of English Language Courses offered by the respective Department of the following universities is given below.

\begin{tabular}{ll}
\hline Name of the University & Name of the respective Department \\
\hline Bangladesh Agricultural University & Department of Language \\
She-re-Bangla Agricultural University & Department of Language \\
Sylhet Agricultural University & Department of Basic Science and Language \\
Chittagong Veterinary and Animal Sciences University & Department of Agricultural Economics and Social Sciences \\
Potuakhali University of Science and Technology & Department of Language and Communication \\
Khulna Agricultural University & Department of English Language Studies \\
\hline
\end{tabular}

There is no Department related to offer English Language Course at BSMRAU of Gazipur, Bangladesh. There are other universities in Bangladesh from where English Language courses are offered from the Department of English.

\subsection{Sylhet Agricultural University}

The Sylhet Agricultural University was officially inaugurated on 02 November, 2006 by the Sylhet Agricultural University Act 2006 which was passed in the National Parliament on 03 October 2006. The university's Faculty of Veterinary and Animal Science came into being through the upgrading of the Sylhet Government Veterinary College (SGVC) as part of the new university. The university campus is located in scenic rural surroundings with small hills and forest with an area of 20.23 hectares (In Campus) and 4.09 hectares (off campus).

Sylhet Agricultural University plays a vital role as a leading international institution of higher learning of Agricultural perspectives in Bangladesh as well as abroad through excellence and innovation in teaching and learning, research and knowledge exchange. It is also contributing to the encroachment of society and the development of leaders through a global presence, regional significance and engagement with the rational activities to fill the demand of time.

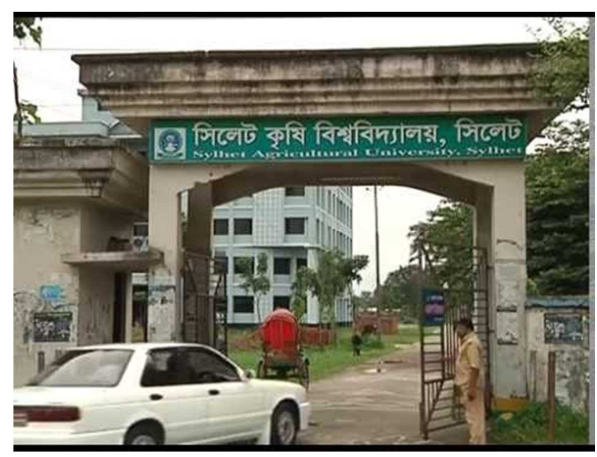

Figure 1. A part of Sylhet Agricultural University Campus. 
Table 2. English Language Courses (Faculty wise) at Sylhet Agricultural University.

\begin{tabular}{|c|c|c|c|}
\hline Name of the Faculty & Number of Courses & Theory & Practical \\
\hline $\begin{array}{l}\text { Faculty of Veterinary, Animal and Biomedical } \\
\text { Sciences }\end{array}$ & Two Courses & Course Title: Communicative English & $\begin{array}{l}\text { Course Title: Communicative } \\
\text { English }\end{array}$ \\
\hline Faculty of Agriculture & Two Courses & $\begin{array}{l}\text { CourseTitle: English } \\
\text { Language }\end{array}$ & $\begin{array}{l}\text { Course Title: English } \\
\text { Language }\end{array}$ \\
\hline Faculty of Fisheries & One Course & CouresTitle: EnglishLanguage & $\begin{array}{l}\text { It has been proposed to } \\
\text { include Practical Course }\end{array}$ \\
\hline $\begin{array}{l}\text { Faculty of Agricultural Economics and } \\
\text { Business Studies }\end{array}$ & Two Courses & Course Title: Basic English & $\begin{array}{l}\text { Course Title: Communicative } \\
\text { English }\end{array}$ \\
\hline $\begin{array}{l}\text { Faculty of Agricultural Engineering and } \\
\text { Technology }\end{array}$ & $\begin{array}{l}\text { Three Courses One } \\
\text { course is Optional }\end{array}$ & $\begin{array}{l}\text { Course Title: English Language Optional } \\
\text { Course: (Commmmunication Skill) is offered } \\
\text { to the students of Level- } 4 \text {, Semester-1 }\end{array}$ & $\begin{array}{l}\text { Course Title: English } \\
\text { Language }\end{array}$ \\
\hline $\begin{array}{l}\text { Faculty of Biotechnology and Genetic } \\
\text { Engineering }\end{array}$ & One Course & $\begin{array}{l}\text { Course: Applied English Language (Theory) } \\
\text { Course No-BSL-111 (T) }\end{array}$ & $\begin{array}{l}\text { No Practical Course is } \\
\text { offered }\end{array}$ \\
\hline
\end{tabular}

At Sylhet Agricultural University, there are six faculties where English Language is taught as compulsory subject and medium of learning is in English. There is a department under the Faculty of Agriculture; Basic Science and Language under which courses on English Language are offered to the learners of all faculties. (http://www.sau.ac.bd/departments/home/176) [13].

The theory course focuses on developing writing skill using appropriate grammatical terms. The practical course develops to improve reading, speaking and listening skills for the learners. The question in final and term examination is set using the action verbs following Bloom's taxonomy. It is the most essential course for the learners to improve communication skill. This course is essential for every student to become proficient in a Foreign Language and discover the multitude of personal and professional opportunities available and collaborate with a diverse group of students and conduct community outreach across cultures. Department of Basic Science and Language offers English Language Learning course for students at all faculties to enhance their professional and workplace skills or develop academically by pursuing a degree at an English-speaking college or university.

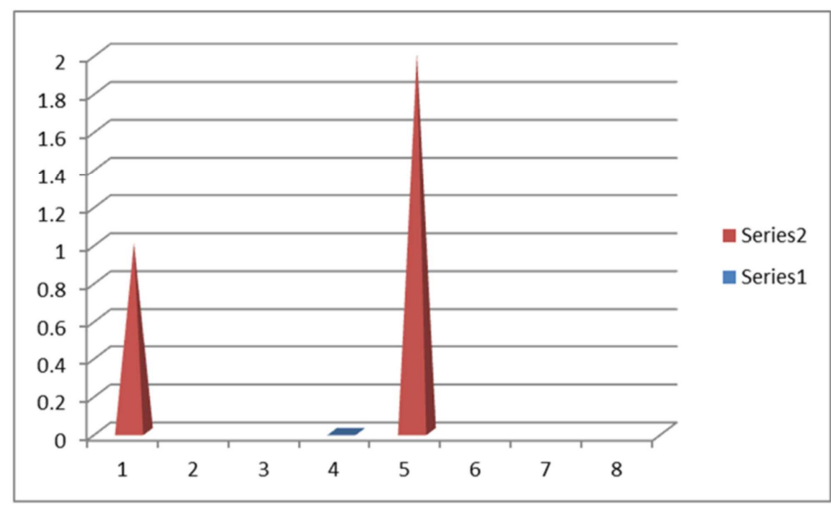

Figure 2. Using Teaching Aids in the EFL Classroom.

The teachers (English) of this university use multimedia and whiteboard with marker in the classroom. Their opinion is that using whiteboard with marker in the class is easier to understand than using multimedia in the classroom. Out of three teachers two teachers teach language through literature and other composition using grammatical terms in writing module. Another one teaches language through different composition using grammatical terms.

In case of theory class the main goal is to write correctly on the basis of any given topic.

In Practical class preference is given to Speaking module and presentation skills. Listening skill is taught using audio visual, power point and other utencils. All teachers use this system in case of teaching practical class.

The medium of instruction of all Agricultural Universities in Bangladesh is in English but there are two versions (English Version and Bangla Version) of education from elementary to higher secondary level. Very few students are taught in English at secondary and higher secondary level. Most of the students are from Bengali version, who faces challenge in higher education. This course is taught at Level1 Semester-1 to overcome the problem and it was first identified by the government at the time of establishing Sylhet and Chittagong Govt. Veterinary College by Department of Livestock, under Ministry of Fisheries and Livestock, Bangladesh. They introduced English Language Course (3 Credits) to the course curriculum for offering degree DVM.

Before it, no courses on English language were offered either at Bangladesh Agricultural University or Agriculture Colleges or Institute. Through the passes of the time and according to the demand of the government this course/ courses is offered to all faculties of all Agricultural Universities in Bangladesh expect BSMRAU, of Gazipur. Now a days the renowned Agriculturists of Bangladesh feel necessary to improve and modify the content of the courses to improve proficiency of English for reading, writing, speaking and listening.

The course has been designed to teach grammatical items and rules of writing so that the learners would be able to write correctly in examination script following accurate rules in a proper way. On the other hand the course curriculum of practical course has been designed to improve speaking, reading and listening skill. On the survey it was found that at Bangladesh agricultural University and Chittagong Veterinary and Animal Sciences University, English Language Lab is available. At Sylhey Agricultural University and Shere Bangla Agricultural University there 
is no established language lab. A sample of course curriculam on English at Sylhet Agricultural University is given below:

\section{Sylhet Agricultural University}

Department of Basic Science and Language

B.Sc. Ag. (Hons) Level-1 Semester-1.

Course Title: English Language (Theory).

Course No-LAN-111(T), Credit-2 Hours, Total Marks:
Course Rationale: Students need to develop reading and writing skills for academic and professional purposes. This course is introduced to teach the students different grammatical rules and application so that they can utilize the techniques in a proper way.

Course Learning Outcome:

Apply grammatical rules to improve written and verbal communication skills. 100 .

Table 3. English Language Course(Theory) taught at Sylhet Agricultural University.

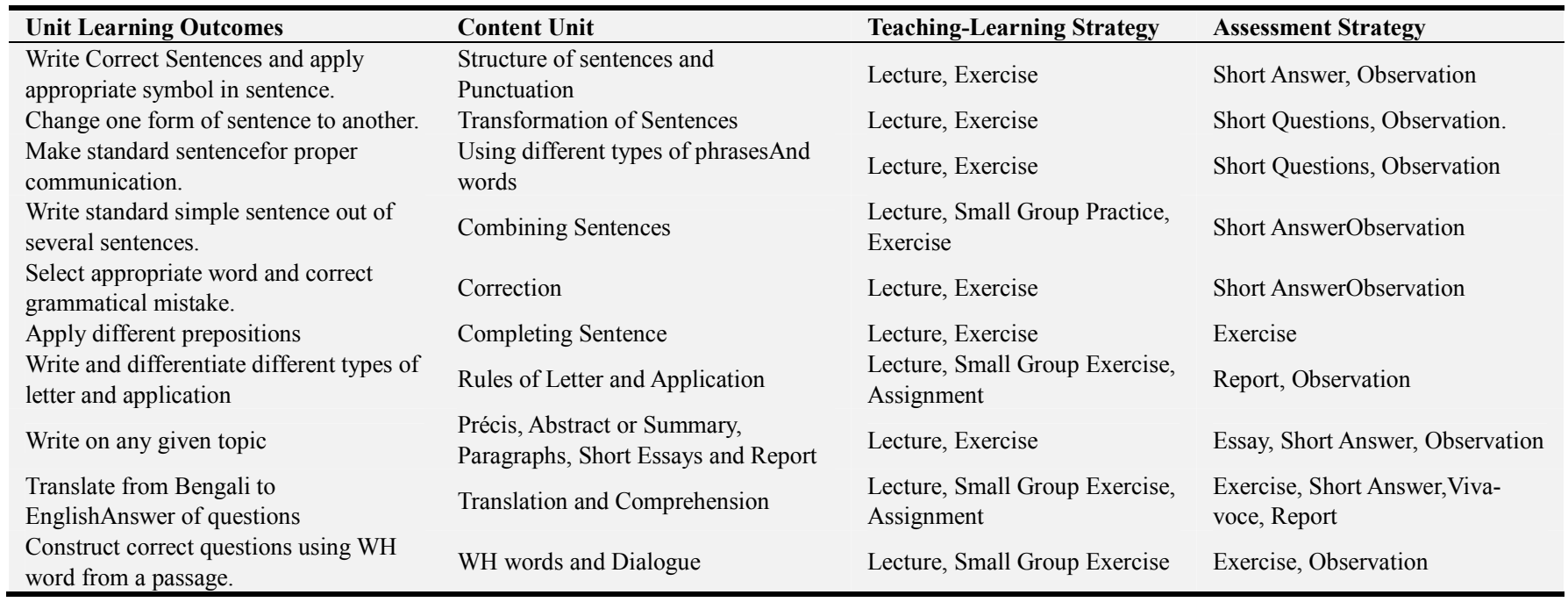

Suggested Reading:

1. From paragraph to essay: Developing Composition Writing, M. Imhoof, Longman Publication.

2. Cambridge Grammar of English, Cambridge Publication.

3. Academic Writing: A Handbook for International Students, London and New York: Routledge.

Sylhet Agricultural University

Department of Basic Science and Language

Course Title: English Language (Practical).

Course No-LAN-422(P), Course Credit:1, Contact Hour-2
Hours Per Week.

Course Rationale: Students need to develop listening and speaking skills for communicative competence. This course is introduced to teach the students phonetics and phonology so that they can understand pronunciation and communicate fluently.

Course Learning Outcome:

Demonstrate command of oral, written and visual literacy skills that enable to exchange messages appropriate to the subject, occasion, and audience.

Table 4. English Language Course (Practical) taught at Sylhet Agricultural University.

\begin{tabular}{|c|c|c|c|}
\hline Unit Learning outcomes & Content Unit & Teaching-Learning Strategy & Assessment Strategy \\
\hline $\begin{array}{l}\text { Differentiate between } \\
\text { phonetics and phonology }\end{array}$ & Phonetics \& Phonology & Lecture, Exercise & $\begin{array}{l}\text { Short Answer, } \\
\text { Observation }\end{array}$ \\
\hline $\begin{array}{l}\text { Apply different symbols in } \\
\text { pronunciation }\end{array}$ & IPA Symbols, Intonation and Stress & $\begin{array}{l}\text { Lecture } \\
\text { Small Group Discussion }\end{array}$ & Observation \\
\hline Talk on any topic & Short Conversation, Long Conversation & Lecture, Debate & ObservationViva Voce \\
\hline Develop listening skills & $\begin{array}{l}\text { Short Conversation through longer conversation to mini } \\
\text { talks, gaining experience in listening. Extensive practice } \\
\text { consisting of watching English dramas on television, } \\
\text { listening to a local radio program. }\end{array}$ & Videotapes & Observation \\
\hline $\begin{array}{l}\text { Write scientific report and } \\
\text { composition by applying } \\
\text { appropriate technique }\end{array}$ & Composition and Report Writing. & $\begin{array}{l}\text { LectureExerciseGroup } \\
\text { Assignment }\end{array}$ & Report \\
\hline
\end{tabular}

Suggested Reading:

1. Gimson's Pronunciation of English, Revised by Alan Cruttenden, University of Manchester.

2. Practical English Usage, Michael Swan, Oxford University Press.
3. English Phonetics and Phonology, Peter Roach, Cambridge University Press.

3.6. Chattogram Veterinary and Animal Sciences University 
Chittagong Government Veterinary college was established in 1995 which later transformed into Chittagong Veterinary and Animal Sciences University. This university was established by the Act of the Government of the People's Republic of Bangladesh on 07 August, 2006. This university is associated with the aforementioned social and economic changes and demands to overcome past weaknesses of the Veterinary and other branches of Agricultural education. education.

There are three faculties; Faculty of Veterinary Medicine, Faculty of Fisheries and Faculty of Food Science and Technology at this university. Two Courses on English Language are offered to each faculty as Compulsory Course; Communicative English (Theory+Practical).

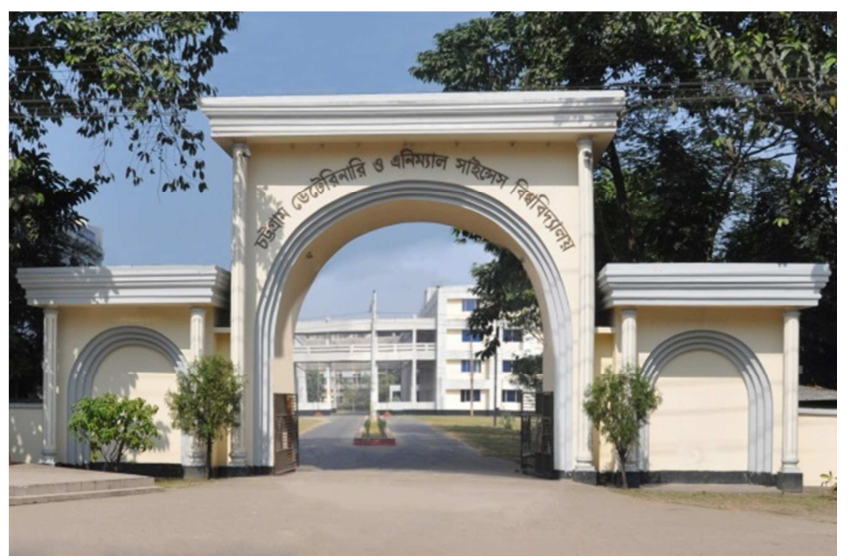

Figure 3. A part of Chattogram Veterinary and Animal Sciences University Campus.

The course curriculum of theory course focuses on grammatical terms and different types of writing module and practical course focuses on reading, speaking and listening module. The theory course focuses on improving writing skill using appropriate grammatical terms of course curriculum. The question set for final and term examination contains different types of action verbs followed by Bloom's taxonomy to evaluate the student properly. The course curriculum of practical course has been set to improve proficiency of reading, speaking and listening skill. At this university there is an established English Language Lab. The teacher uses whiteboard with marker and power point in theory class but uses power point and other modern equipments in the classroom. (Source: https://en.wikipedia.org/wiki/Chittagong_Veterinary_and_An imal_Sciences_University) [14].

\subsection{She-re-Bangla Agricultural University}

Shere-Bangla Agricultural University is located at Sherebangla-Nagor, Dhaka, Bangladesh. SAU was established as Bengal Agricultural Institute (BAI) on 11 December 1938 The Bengal Agricultural Institute was renamed East Pakistan Agricultural Institute in 1947. After the emergence of Bangladesh as an independent country in 1971, the name of the institute was spontaneously changed to Bangladesh Agricultural Institute (BAI). Since its inception in 1938, the BAI had been functioning as a Faculty of Agriculture under Dhaka University. After the establishment of Bangladesh Agricultural University (BAU) at Mymensingh in 1961 its academic function was transferred to BAU in 1964 until its upgrade to Sher-e-Bangla Agricultural University in 2001.

This university was established for the expansion of higher agricultural education and committed to promote research in various fields of agricultural sciences and to offer extension services.

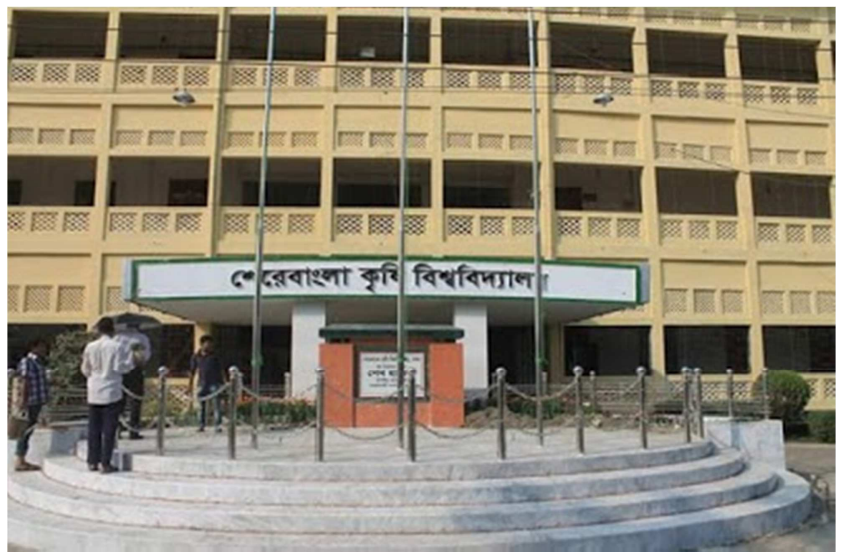

Figure 4. A part of She-re-Bangla Agricultural University Campus.

Table 5. English Language taught at She-re-Bangla Agricultural University.

\begin{tabular}{|c|c|c|}
\hline Name of the Faculty & Offered Course (Theory) & Offered Course (Practical) \\
\hline Faculty of Agriculture & Advanced Language Skills (Theory) & No Practical Course is offered. \\
\hline $\begin{array}{l}\text { Faculty of Animal Science and Veterinary Medicine } \\
\text { Faculty of Agribusiness Management }\end{array}$ & Advanced Language Skills (Theory) & Advanced Language Skills (Practical) \\
\hline BBA in Agribusiness & Basic English (Theory) & Basic English (Practical) \\
\hline B. Sc in Agricultural Economics & Basic English (Theory) & Basic English (Practical) \\
\hline Faculty of Fisheries and Aquaculture & Communicative English (Theory) & Communicative English (Practical) \\
\hline
\end{tabular}

English is taught as compulsory subject from all faculties but from the faculty of Agriculture it is offered as Optional Course. The theory course has designed how to develop writing skills following appropriate grammatical terms and to write any composition and other form of writing. The Practical Course has been designed to develop communication skills as well as listening, reading and writing skills. In case of teaching all teachers do the same in the classroom. They prefer to use white board with marker to power point in theory class.

\subsection{Patuakhali University of Science and Technology}

Potuakhali University of Science and Technology is situated at Potuakhali and it is upgraded as University from 
Potuakhali Agriculture College in 2000.

The university was inaugurated on 08 July 2000 by the then Honorable Prime Minister, Government of the Peoples Republic of Bangladesh, Her Excellency Sheikh Hasina started its academic activities on 26 February 2002.
English is taught as compulsory subject to all faculties offered by Department of Language and Communication. The course has also been designed on improving writing ability using appropriate grammatical terms and to develop communication skills on reading, writing, speaking and listening.

Table 6. English Language taught at PUST.

\begin{tabular}{lll}
\hline Name of the Faculty & Name of the Course (Theory) & Name of the Course: Practical \\
\hline Agriculture & Basic English (Theory) & $\mathrm{x}$ \\
Business Administration & English Language (Theory) & Business Communication and Report Writing (Practical) \\
Computer Science and Engineering & Communicative English (Theory) & $\mathrm{x}$ \\
Fisheries & Communicative English (Theory) & $\mathrm{x}$ \\
Disaster Management & Communicative English (Theory) & $\mathrm{x}$ \\
Land Management & Communication Skills (Theory) & $\mathrm{x}$ \\
Nutrition and Food Science & English: Rethoric and Composition & $\mathrm{x}$ \\
\hline
\end{tabular}

(Source: Chairman, Department of Language and Communication, PSTU)

Another two faculties of this university: Faculty of Veterinary Science and Faculty of Animal Husbandry is situated near Barisal where English Language is taught as compulsory subject.

Courses offered by the Department of Humanities and Social Science of a specialized University are given below:

\subsection{BUET}

Bangladesh University of Engineering and Technology (BUET) is one of the most prestigious institution for Engineering education in Bangladesh. Ahsanullah Engineering College was upgraded to the status of a university in 1962.

It may be pointed out that at Bangladesh University of Engineering and Technology (BUET), there is a Department named Department of Humanities from where English Language courses are offered.

The Department of Humanities offers courses in different disciplines of Humanities, Social Science and Commerce. The courses offered by this Department to the undergraduates of different Departments of Bangladesh University of Engineering and Technology (BUET) are English, Sociology, Economics, Political Science, Accounting, Management, Philosophy, Psychology etc. (Source: http://hum.buet.ac.bd) [15].

Table 7. English Languahe taught at BUET.

\begin{tabular}{llll}
\hline Subject: English & & & \\
\hline Course No. & Course Name (Theory) & Credit & Department \\
\hline Hum-101 & English & 3.00 Credit & ME, MME \\
Hum-111 & English & 2.00 Credit & WRE, NAME \\
Hum-125 & English & 2.00 Credit & URP, CHE \\
Hum-135 & English & 3.00 Credit & EEE \\
Hum-183 & English & 3.00 Credit & CSE \\
Hum-185 & English & 2.00 Credit & CE \\
Hum-187 & English & 3.00 Credit & BME \\
Hum-207 & Advanced English & 2.00 Credit & MME, WRE \\
Hum-705 & English & 2.00 Credit & ARCH \\
Hum-711 & Literature Studies & 2.00 Credit & ARCH \\
Course No. & Course Name (Sessional) & Credit & Department \\
Hum-102 & English Language Practice & 1.5 Credit & IPE, NAME \\
Hum-104 & English Skills Sessional & 1.5 Credit & BME \\
Hum -138 & English Language Practice & 1.5 Credit & CHE, URP, EEE \\
Hum-272 & Developing English Skills & 1.5 Credit & CSE \\
Hum-172 & Developing English Skills & 1.5 Credit & CE, WRE \\
Hum-274 & Developing English Skills & 1.5 Credit & \\
\hline
\end{tabular}

\section{Conclusion}

It may be concluded here by saying that English is taught as a compulsory subject at most Agricultural Universities in Bangladesh. The courses vary from university to university according to the decision of the authority of the university. Most of the faculties of each university offer Communicative
English (Practical) which is essential to develop reading, speaking and listening skills and theory course has been designed to develop writing skills. In comparison to Bangladesh University of Engineering and Technology, it may be pointed out that most of the faculties of both types of specialized universities offer two courses on English Language (Theory + Practical). The system of teaching is near the same due to related course curriculum. At Post 
Graduate Level no English Language course is offered but it is essential due to necessity of the demand of present world.

\section{References}

[1] Wright, 2010. Second Language Teacher Education: Review of Recent Research on Practice. Language Teaching 43 (3), $269-296,2010$

[2] Farooqui, S. (2008). Teachers' perceptions of textbook and teachers' guide: A study in secondary education in Bangladesh. Journal of Asia TEFL, 5 (4), 181-200.

[3] Carless, D. R. (2004) A contexualised examination of target language use in the primary school foreign language classroom. Australian Review of Applied Linguistics, 18, 104119.

[4] Kang, D. (2008). The classroom language use of a Korean elementary school EFL teacher: Another look at TETE. System, 38, 214-226.

[5] Nunan, D. (2003). The impact of English as a global language on educational policies and practices in the Asia-Pacific region. TESOL Quarterly, 37 (4), 589-613.

[6] Orafi, S. M. S., \& Borg, S. (2009). Intentions and realities in implementing communicative curriculum reform. System, 37, 243-253.

[7] Shin, S. (2012) It cannot be done alone: The socialization of novice English teachers in South Korea. TESOL Quarterly, 46 (3), 542-567.

[8] Su, Y. (2006). EFL teachers' perceptions of English language policy at the elementary level in Taiwan. Educational Studies, 32 (3), 265-283.

[9] Haider, M. Z., \& Chowdhury, T. A.(2012). Repositioning of CLT from curriculum to classroom: A review of the English language instructions at Bangladeshi secondary schools. International Journal of English Linguistics, 2 (4), 12-22.

[10] Bala, Swapan Kumar (2012). "University Grants Commission". In Islam, Sirajul; Jamal, Ahmed A.

[11] Kazi Shahidullah: 2019". The Daily Star. 2019-05-22. Retrieved 2019-05-23.

[12] http://www.newsbangladesh.com/english/details/10341.

[13] http://www.sau.ac.bd/departments/home/176.

[14] https://en.wikipedia.org/wiki/Chittagong_Veterinary_and_Ani mal_Sciences_University.

[15] http://hum.buet.ac.bd. 